\title{
Continuidade ou Ruptura na História do Brasil Império?
}

\author{
Continuity or Rupture in the History of the Brazilian Empire?
}

\author{
Beatriz Piva Momesso \\ Doutor em História \\ Instituto Histórico, Geográfico e Genealógico de Campinas \\ beatrizmomesso@gmail.com
}

Resumo: O artigo, num esforço historiográfico, busca demonstrar como ao longo da história do Brasil Império as ações políticas de grupos dirigentes do Estado contrastaram, mesclaram-se ou mesmo coexistiram com atuações dos grupos sociais distantes entre si. $\mathrm{O}$ resultado da interação dessas diversas forças sociais: trabalhadores, burocratas, profissionais liberais, comerciantes, homens livres pobres, escravizados e libertos teria produzido uma temporalidade própria na História do Império marcada pelas transformações situadas num ponto entre a inércia e a rapidez. A partir da análise dos artigos da Revista do IHGB produzidos no século XIX e de obras escolhidas dentre produção de historiadores reconhecidos que abarcam a Independência, Regência e o Segundo Reinado, o artigo destaca, primordialmente, as continuidades temporais em detrimento de rupturas, colocando em dúvida a síntese como produto necessário do embate de forças históricas.

Palavras-chaves: continuidades, Brasil Império, forças sociais.
Abstract: By means of a historiographical effort, this article seeks to demonstrate how the political activities of the State leading groups contrasted, merged or even co-existed with different social groups during the history of the Brazilian Empire. The result of the interaction by these various opposing social forces: workers, bureaucrats, liberal professionals, traders, poor free men, enslaved and freed would have produced a temporality which is typical of the History of the Empire which is marked by the transformations between the inertia and speed. By analyzing the articles published by the IHGB Magazine produced in the XIX century and the works of acclaimed historians who address the Independence, The Regency and the Second Reign, the article highlights, primarilly, the temporal continuities at the expense of ruptures, questioning the synthesis as a necessary product of the historical forces.

Key words: continuities, Brazil Empire, social forces. 



\section{Percepção do Passado e horizonte de expectativa}

François Hartog fez uso da categoria regime de historicidade para observar a condição histórica de uma sociedade, isto é, a maneira possível de percepção do passado, do presente e do futuro por seus próprios integrantes. O historiador tendo como referência esse instrumental é capaz de estudar a inserção de um personagem em determinado contexto limite, passível de imediatas mudanças; ou ainda captar as continuidades e rupturas ocorridas ao longo da passagem do tempo e, por sua vez, conservadas em diversas esferas de uma sociedade. (HARTOG, 2013: 17-41)

Em sentido teórico, tratando-se da História do Império Brasileiro, nesta análise, o conceito de regime de historicidade permite a percepção das continuidades em detrimento das formas dialéticas gestadas em longo prazo. Ainda que grupos sociais com interesses distintos, desde burocratas até rebeldes do povo, tenham desencadeado mudanças reais, o Brasil oitocentista apresentou transformações gradativas e cadenciadas, por vezes lentas que se diferenciaram das grandes sínteses hegelianas, produto de antíteses radicais.

Toda uma concepção de História foi forjada pelo pensamento idealista de Georg W. Friedrich Hegel (1770-1831). Para este filósofo, que mesclou iluminismo e fé, existe um desenvolvimento da Razão ou do Espírito que se manifesta no tempo e toma consciência de si por um ritmo ternário o que, por sua vez, caracteriza o movimento dialético. Tal moviemento comporta três momentos: a tese (o ser), a antítese (o não ser) e a síntese (o devir). A síntese significa o novo produto, uma nova identidade da Razão resultante do conflito entre as premissas anteriores (tese e antítese). Acontece que, neste sistema filosófico, a concepção de História é marcada necessariamente pelo progresso como superação do atraso. O próprio pensador afirma: "A marcha e movimento do Espírito não é repetição, mas transformação na tomada de consciência de si. O aspecto mutável que o Espírito reveste é o progresso" (HEGEL, 2013: 122-123).

Em grande parte, os clássicos a respeito da História do Brasil Imperial trazem a tona a ideia de que as transfromações histórias não eliminaram certos elementos políticos e culturais remanescentes de tempos anteriores e prolongaram a existência de características análogas tanto à sociedade do período joanino quanto à sociedade às portas da proclamação da república. A concepção hegeliana de constante superação do devir no desenvolvimento da História não parece embasar, na prática, a escrita da 
História dos relevantes autores que compuseram a historiografia do Brasil oitocentista, que aqui vamos enfocar, ainda que muitos deles se considerem adpetos do sistema dialético. Iniciaremos pelos escritos do século XIX e terminaremos com a análise de consagrados historiadores contemporâneos especialistas nesse período enfocado.

Em todo caso, algo inegável e válido para a História Política do Império é a condução intencional do presente, ou do espaço de experiência como pensou Koselleck, em função de um horizonte de expectativa (KOSELLECK, 2006). Portanto, a História do Brasil Império não foi fruto do acaso ou da passividade. Resultou de um planejamento estratégico, mesmo que em sua execução nem sempre tivesse contemplado os objetivos inicialmente estabelecidos. É a partir de tal intencionalidade que se entenderá o embate ou coexistência entre grupos de trabalhadores, comerciantes, escravos, ex-escravos, libertos, homens livres pobres, profissionais liberais, comerciantes, burocratas e grandes agriculturoes, dentre outros, cujas ações resultaram na construção da História do Império e que provocaram transformações caracterizadas por vários elementos de continuidade e um ritmo temporal próprio, lento, em que o passado se apresenta no presente.

\section{Política e Tempo nas Esferas de Poder do IHGB}

A escrita da História do Brasil Império esteve ancorada, inicialmente, no projeto de produção de certa memória, capaz de conferir identidade e coesão ao Estado Brasileiro. Tal operação foi largamente estudada e debatida na última década por meio dos trabalhos de Manoel Salgado e Lucia Guimarães (GUIMARÃES, 1988; GUIMARÃES, 2011). Os recursos culturais constituíram meio para a afirmação da História Política e o IHGB era o local onde, desde 1838, homens de letras, estudiosos da fuana e da flora, minerólogos e políticos próximos ao Imperador preocupavam-se em preparar o futuro, isto é, buscaram singularizar e dar cores à nação brasileira de modo a que esta se inserisse num mundo civilizado. Tratava-se de escrever uma história autoexplicativa integrando o branco, negro e o índio, como já é sabido. Uma história onde predominasse uma narrativa que harmonizasse as diferenças entre tais grupos, de forma a mostrar de modo convincente a contribuição positiva e única de cada um destes elementos para a formação da identidade brasileira. 
O projeto específico do IHGB foi embasado por permanências na medida em que a identidade brasileira não deveria ser plasmada em oposição à antiga metrópole, mas como continuadora de uma certa tarefa civilizadora portuguesa Embora fosse singular, buscava-se mostrar por meio da definição de tal identidade as contribuições do Brasil para um mundo global, onde o conhecimento, a riqueza e as solidez nas instituições e na economia eram fundamentais para o progresso ordenado. $\mathrm{O}$ que significa que o ideal de ilustração herdado de Portugal, foi de suma importância para a criação de um novo país, merece destaque e deve ser ressaltado entre os traços da nova nação autônoma. Se os tempos são novos, há valores passados que devem permanecer no presente. Daí a existência dos membros ilustrados no instituto e de expedições científicas para reconhecer novos minerais, espécies e catalogar tipos humanos. No entanto, através da mistura dos três elementos: o branco-português, índio e negro buscase o embranquecimento e o predomínio do primeiro, aquele, de fato, civilizado graças a um aprendizado anterior, e, portanto, capaz de empurrar o Império para o progresso.

A ideia de aprender com o passado através de seus homens e fatos singulares, sem dúvida, compunha o projeto de nação. Assim se explica a preocupação com os clássicos e a citação dos antigos, modelos de virtude e a intenção de delimitar e enriquecer um panteão de heróis, em especial os personagens políticos da História. A história seria magistra vitae (KOSELLECK, 2006). No entanto, enganam-se aqueles que pensavam que o IHGB vivia apenas do passado- no presente, da memória ou de um presentismo predominante. Os discursos dos membros da instituição também demonstram que o presente era intensamente vivido também em prol de um futuro, onde o Brasil estaria inserido particularmente no hall das grandes nações, sendo bem quisto e capaz de obter vantagens dessa condição. Nesse sentido, entende-se, por exemplo, a preocupação, por difundir notícias e registrar a participação do Brasil nas exposições mundiais.

Mas havia um projeto futuro estrutural e subentendido. O IHGB tinha por objetivo colaborar para a duração e permanência da monarquia mediante a difusão da imagem do regime político moderno, capaz de atender às demandas políticas europeias, isto é, um regime ilustrado, harmonioso e que cumpria eficazmente a vocação agrícola do Brasil na ordem mundial organizada pelo velho mundo. A leitura continuada das revistas permitem entrever a ideia de que a modernidade era um conceito correspondente ao regime imperial, personificada no Imperador do Brasil. Nas linhas abaixo, onde lê-se os elogios do presidente do IHGB Visconde de São Leopoldo a Dom 
Pedro II por ocasião de seu aniversário natalício, a razão de ser do Instituto também revela-se:

Senhor, nas monarquias hereditárias foi sempre saudado com entusiasmo o natalício dos soberanos, nele contemplam os povos a perpetuada paternidade política, que torna do Estado uma família, nele reconhecem renovada essa substituição recíproca de direitos e deveres, de encargos e recompensas, aliança que no decorrer dos séculos cada vez mais se estreita; e se tais sucessos são memoráveis em circunstâncias ordinárias, de quanta maior importância não será para nós, entre as procelas que agitam os governos apenas constituídos, o aniversário deste dia em que dádiva do céu luziu no mundo, emanação do seio das divinas misericórdias para penhor e estabilidade do Império e para bem aventurar seus futuros destinos. [sic.] (SÃO LEOPOLDO, 1842: 530). ${ }^{1}$

O governo Imperial, pelas páginas do IHGB, aparece retratado como o governo seguro e estável, o monarca como pai e o Estado como família. Um pai que tentava governar seus filhos de forma exemplar, que viajava sem fazer uso do dinheiro público e estava por dentro de todas as obras públicas ou decisões ministeriais e, ao mesmo tempo, acompanhava os mínimos detalhes da vida cultural brasileira. Nesse sentido, resplandece no fragmento anteriormente citado não só a explícita ligação entre o instituto histórico e o ilustrado imperador, a "quem ela (a instituição) deve sua literária existência", mas também a proposta de fixar memória. Não por acaso a saudação de São Leopoldo apareceu na RIHGB em 1842. Tratava-se de um momento delicado, quando era necessário conferir apoio à monarquia constitucional, já que revoltas locais liberais eclodiam em São Paulo e Minas e constituíam exemplos de contestação do regime centralizado, dois anos após o Golpe da Maioridade. Portanto, caberia à revista ressaltar as qualidades da autoridade máxima do país e lembrar a todos as maravilhas da insituição imperial, que deveria continuar predominando, por ser um regime político moderno, seguro e familiar. A projeção de tempos vindouros era anunciada pelas páginas do IHGB, numa tentativa de estabelecer uma monarquia in continum, isto é, uma monarquia que teria continuidade no futuro do país.

1 A ortografia foi atualizada. 
A instituição também foi responsável pela divisão da História do Brasil na temporalidade a partir da qual até hoje se organizam os currículos no ensino fundamental e médio e até mesmo nos cursos de graduação nas universidades brasileiras. Lúcia Guimarães estudou o primeiro Congresso de História ocorrido em 1914 e demonstrou que as premissas orientativas de trabalho apoiavam-se nas diretrizes definidas por Charles Langlois e Simeand, fundadores da Escola Metódica Francesa (1876-1840) que atribuíam grande ênfase à História Política e ao uso da cronologia no entendimento do desenvolvimento dos fatos e suas circunstâncias. Em suma, tratava-se de pensar a História através de grandes marcos determinados por heróis em acontecimentos políticos em uma contínua evolução (GUIMARÃES, 2006: 162-181).

Não por acaso, naquela ocasião, decidiu-se que a História do Brasil fosse dividida em Período Colonial e Imperial. Os congressistas demarcaram como marco inicial e final do Estudo da História do Brasil 1500-1871. A opção se justificou pela preocupação com o esquecimento contemporâneo do Segundo Reinado, momento histórico importante necessário para o real entendimento da nacionalidade. A escolha por 1871 justificou-se pela noção defendida pelo IHGB de que certo distanciamento do presente seria necessário para analisar os fatos com certa imparcialidade. (GUIMARÃES, 2006: 162-181)

De todos os modos, é patente a preferência dos sócios do Instituto pelo período imperial ao tratar da História do país, em pleno século XX, quando o regime de governo adotado era republicano há decadas. As publicações do Instituto no período subsequente ao I Congresso de História corroboraram a tese de que era necessário fazer memória de subperíodos do Império a fim de promover o sentimento nacional brasileiro. Embora o tema ainda deva ser estudado nesta temporalidade, uma passada de olho rápida nos índices da revista da primeira metade do século $\mathrm{XX}$, revela a predominância de artigos e temas de estudo cujo objeto era o regime imperial e suas interfaces. Por exemplo, no número publicado ainda em 1914 há uma seção intitulada Notas de Dom Pedro II que traz a tona opiniões do monarca sobre temas ecléticos entre si anotadas no exemplar de um livro a ele oferecido pelo Visconde: curiosidades naturais do Paraná, impressões a respeito de familiares do autor, sua interpretação sobre a partida da família real, notas sobre sua biblioteca particular e sobre André Rebouças. O exemplar foi tratado como relíquia, oferecido meses antes pela família de Taunay ao IHGB e foi considerado precioso material sobre o venerável Imperador (TAUNAY, 1914: 69-80). 
Outro exemplo: a revista de número 79, publicada em 1917, dedicou integralmente as quase seiscentas páginas para a análise da Independência do Brasil, destacando o tema do Fico e a participação de José Bonifácio, a partir do olhar de Varnhagen. A reunião da Constituinte e sua dissolução também foram incluídas na publicação. Como parte do resumo daquela edição, famosos sócios relembraram a presença de Pedro I na Constituinte e destacaram sua importância para o processo de emancipação do Brasil (RIHGB, 1917:100-103)

Portanto, parece notável que temas relativos à Independência e ao Segundo Reinado continuem presentes de modo proeminente nas páginas da Revista do IHGB, passados quase trinta anos da implantação do regime republicano, fazendo lembrar ao leitor a grandeza e vigor do Império, perpetuando a memória de um regime político que não deveria ser esquecido e que permanecia vivo na primeira metade do século $\mathrm{XX}$, ao menos em espírito, no que dependia dos promotores daquela instituição de saber.

\section{Historiografia e continuidade no Império Brasileiro até 1840}

A Historiografia das últimas décadas apresenta interessantes versões sobre a Independência do Brasil destacando a permanência de elementos culturais e políticos oriundos do mundo português, que compartilhados explicam, em parte, as resistências iniciais à independência. Maria Odila Leite da Silva Dias (2005) é a precursora dessa tese em a Interiorização da metrópole e outros estudos, especialmente no Capítulo 2 intitulado "Aspectos da Ilustração Brasileira", publicado pela primeira vez na Revista do IHGB, em 1968, e que muito inspirou estudos que vieram posteriormente como as obras de José Murilo de Carvalho e Lúcia Bastos. ${ }^{2}$ É nesse sentido que a seguir será tratada a independência do Brasil, como um processo, que a priori, deu-se contra a vontade da maioria.

Em primeiro lugar, a autora demonstrou a existência de uma mentalidade ilustrada da geração que integrou o processo de independência, a partir do viés da formação intelectual. Ora, em sua maioria, esses brasileiros formaram-se em direito na Universidade de Coimbra, ou em algum caso ou outro na Universidade de Paris,

$2 \mathrm{O}$ artigo que deu origem ao capítulo 2 de A Interiorização da metrópole e outros estudos foi publicado originalmente na Revista do IHGB, em 1968, com o mesmo título e algumas poucas reduções de texto se comparado ao capítulo de livro. Consta nas referências bibliográficas finais. 
Edimburgo ou Montepellier. Sendo assim, partilharam do Iluminismo que seria aquele de Locke, mas jamais o de Rousseau, quer dizer: clamavam pelos direitos de propriedade, mas não de igualdade ou democracia. As listas de livros dessas universidades comprovam a prioridade desse tipo de leitura.

Tratava-se de uma geração ilustrada de um pragmatismo apreendido em Portugal, na medida em que além do direito, a maioria desses acadêmicos dispunha de formação em carreiras de ciências experimentais, esse foi o caso de José Bonifácio. Muitos desses bacharéis e cientistas, por exemplo, uniram-se em torno de Dom Rodrigo de Sousa Coutinho, absolutista ilustrado que se tornou ministro de Dona Maria em 1796, a fim de empreender uma política de renovação da agricultura e da introdução de novas técnicas rurais em todo o Império Português incluindo Brasil, Moçambique e Angola. Tratava-se então de uma política de Estado que promovia a integração ultramar direcionados pelo ideal de progresso material e modernização (DIAS, 1968: 108-118)

Por exemplo, o médico brasileiro José Pinto de Azeredo viajou para as terras africanas do Império para estudar algumas enfermidades, antes de dedicar-se ao combate de doenças endêmicas no Rio de Janeiro. O jornal O Patritota, publicado a partir de 1813, dispunha de certo espaço dedicado às ciências bem maior que aquele dedicado às letras e tal como o Correio Braziliense. Editado por Hipólito da Costa, a publicação ocupava-se, no início do século, de divulgar a mentalidade ilustrada, herdada de Pombal.

Esses dois veículos de imprensa brasileira trataram, quase até vésperas da independência, de divulgar ideias liberais de viés econômico, como melhoria da agricultura que permitiria o incremento do comércio ou também incrementos tecnológicos para otimizar a navegação.

José Bonifácio, Hipólito da Costa e o próprio Martin Andrada seriam exemplos de políticos diplomados também em Ciências Naturais que explicam o fenômeno moderado da Independência. Mais preocupados com a ordem e o progresso, formados no Antigo Regime, marcados pela origem aristocrática e rural e participantes do despotismo ilustrado de Dom Rodrigo Coutinho, também se preocupavam mais com a mineralogia que com estudos filosóficos sempre mais perigosos para os antigos privilégios e para a ordem constituída (DIAS, 2005:152).

Tratava-se enfim, segundo essa tese da totalidade do Império Português, de reformar o Reino a partir do Brasil durante a estada da família real, usando a ciência. Ao que tudo indica os bacharéis ilustrados brasileiros só desistiram desse ideal no 
momento em que se acentuaram as diferenças entre brasileiros e portugueses de modo a tornar a união incômoda. Então passaram a aceitar a ideia de separação.

A temporalidade marcada por certa longa duração se rompe em alguns pontos pela extrema necessidade de defesa de interesses que já não se coadunam. Esse parece ser o prinicipal fator explicativo. Maria de Lourdes Viana Lyra explicou o fato através da imagem que chamou de a Utopia do Poderoso Império encabeçado por Portugal e Brasil. A vinda de Dom João VI integrou o projeto de reestruturação do Império Português a partir do Novo Mundo, tratava-se de uma forma de dominar o atlântico e garantir a prosperidade dada a importância do Brasil para a Economia Portuguesa, concebido anteriormente à invasão napoleônica a Portugal. À oposição das Cortes Portuguesas que reivindicavam a volta do rei e o fim da inversão metropolitana, o grupo liderado por José Bonifácio- coligação do Rio de Janeiro, Minas e São Paulo- defendia a causa da liberdade.

No entanto, como salientou Viana Lyra, o grupo de José Bonifácio desejou participar das Cortes, defendendo a reciprocidade entre as partes a fim de "resguardar as relações de parceria segundo diretrizes iniciais do projeto de construção de um só Império Português" (LYRA, 1994: 203). Apresentava-se um pacto com igualdade de direitos e venturas.

Tal segmento, ao que tudo indica, quis acomodar os interesses divergentes, negociando inclusive a ida a Portugal de deputados brasileiros para integrar as cortes. $\mathrm{O}$ que em geral temia era a divisão do reino e, posteriormente, a proposição de uma república para o Brasil, o que ameaçaria a unidade, a tradição monárquica e, sobretudo, a ordem social com a reivindicação de direitos políticos e civis por parte de minorias sociais. A lembrança de Revoluções como a de 1817 reanimava a todos a afastar tal espectro da república.

Uma vez que os regeneradores portugueses não abriram mão das vantagens econômicas no comércio brasileiro, bem como de suas prerrogativas de antiga sede se deu ruptura. A tentativa de manter a utopia do poderoso Império permaneceu, mas adquiriu novas cores. Àquela altura, tratava-se de unir o Poderoso Império Brasileiro com todas as suas províncias em torno de Dom Pedro I, a fim de impedir a desagregação e a anarquia.

Em maio de 1822, o Senado concedeu a Dom Pedro I o título de defensor perpétuo e a convocação de uma Assembleia Constituinte. Dom Pedro "salvaria a realeza nesse grande continente americano" (LYRA, 1994: 214). O Manifesto Redigido 
por Gonçalves Ledo, congregando todas as províncias a se posicionarem em torno do Príncipe, evocou a identidade do Brasil que ao unir-se em torno de um monarca que seria posteriormente constitucional, fugia de políticas obscurantistas das cortes e se congregava perante o liberal e ilustrado monarca definido como“ a porção mais rica da nação portuguesa” (LYRA, 1994: 217)

Por ocasião da Independência, vários grupos distintos associaram-se. |Lúcia Pereira das Neves refere-se aos coimbrães e à elite brasiliense. Os primeiros eram graduados nas universidades do Brasil ou Lisboa, prestavam serviço público, detinham um ideal reformador moderado e pretendiam manter a união com Portugal, superando o sistema colonial, sem retrocesso em relação ao período vivido na condição de Reino Unido. Já os membros da elite brasiliense, cujo significativo expoente foi o jornalista Gonçalves Ledo, não tinham estudos universitários, alguns poucos haviam frequentado cursos superiores na França e a imprensa era o único contato com o mundo estrangeiro. A priori eram separatistas. Não descartaram, no entanto, a hipótese de um império exclusivamente brasileiro, caso fossem ameaçados os princípios de liberdade e igualdade de direitos, que julgavam estabelecidos, como de fato ocorreu. (NEVES, 2003:255). É surpreendente constatar que Frei Caneca foi o orador da Missa Solene de Aclamação ao Imperador, ocorrida em dezembro de 1822. Justo ele que fora participante de 1817 e preso em 1821 (LYRA, 1994: 223)

Como foi observado, todos esses elementos denotam um sóbrio e gradual processo de emancipação, seja pela herança ilustrada portuguesa que conduziu a um reformismo ou liberalismo moderado, seja pelo desejo de manter um império onde a monarquia constitucional vigorava como garantia de continuidade da ordem e permitia uma maior liberdade política no âmbito das decisões internas e da economia.

Tratando-se da Assembleia Constituinte de 1824, as continuidades são latentes, embora nem sempre à primeira vista sejam explícitas. Desde 1823, alguns deputados propuseram que a cidadania se tornasse sinônimo de nacionalidade, isto é, todos os nascidos no Brasil incluindo ex-escravos e indígenas seriam integrantes da sociedade civil, sem deter direitos políticos. Tal ação significou a intenção de dividir os cidadãos entre ativos e passivos (SILVA, 2002: 61-63). Que continuidade se observa aí? Ora, verifica-se a permanência do pacto social baseado na preservação da propriedade também pela economia de direitos políticos dos novos cidadãos.

Um bom exemplo do que se diz é a condição dos libertos na Constituição de 1824. Segundo a nossa primeira carta: os libertos ainda que não pudessem ser eleitos, 
poderiam participar das eleições primárias como votantes. Alguns historiadores como Keila Grinberg enxergaram nessa resolução a ação de dispositivos jurídicos liberais que fizeram com que os escravos tivessem a cidadania no seu horizonte de expectativa e que, ao mesmo tempo contribuía para aproximar os libertos do universo dos escravos, através da restrição parcial de direitos. No entanto, há certa agudeza, no argumento de Andreia Slemian, segundo o qual o liberalismo reforçou a distinção entre homens livres e escravos e "visava na concepção normativa da maioria dos que compuseram a Assembleia, a manutenção da estabilidade desse sistema." (SLEMIAN, 2005: 844). Os libertos, de alguma forma, distanciaram-se civilmente de seus companheiros de cor escravizados, a cor passou a um segundo plano como critério de distinção social. $\mathrm{O}$ liberalismo conservador procedeu à construção constitucional da cidadania e logrou maior controle sobre os escravos que passaram a almejar a os direitos juridicamente inerentes à condição de libertos (SLEMIAN, 2005:847).

Grosso modo, as sociedades, facções ou grupos políticos aceitaram a independência respaldada pelo elemento monárquico, já que esta garantiria a inserção do Brasil nas luzes do progresso material e da ordem política. No entanto, à medida que o Primeiro Reinado avançava, vislumbram-se com nitidez rusgas entre absolutistas e liberais bem como conflitos envolvendo as massas nas ruas. Os conflitos protagonizados por portugueses são talvez, um exemplo gráfico do que aqui se discute. Em que sentindo tais acontecimentos assumiriam significados relacionados à ruptura do mundo brasileiro liberal e o mundo português entendido como absolutista?

Os conflitos envolvendo lusos e brasileiros remontam os anos que antecederam a Independência, prolongaram-se com intensidade na Regência e estenderam-se ao Segundo Reinado. De fato, a entrada de estrangeiros, incluindo-se portugueses, era regulada pela Corte estabelecida no Brasil, como comprova o Decreto de 02 de dezembro de 1820. Na ocasião, havia uma real preocupação com a circulação das ideias liberais e recolonizadoras e nesse sentido, justifica-se a necessidade do controle dos imigrantes ibéricos. Ainda nos anos imediatamente posteriores à independência havia o medo da ação dos portugueses estabelecidos na Bahia e Pernambuco, regiões conhecidas pelas ideias revolucionárias (RIBEIRO, 2002: 33-34).

No entanto, as distintas políticas do Primeiro Reinado e da Regência coincidiram ao não dificultar a aquisição de nacionalidade pelos lusos. No Primeiro Reinado, sobretudo, se o governo, por um lado, não deixasse de controlar e vigiar os que aqui estavam estabelecidos exigindo deles cartas de seguro firmadas pelos cônsules ou 
registro em livros de escrituração para estrangeiros; por outro, também acolhia aqueles que aderiram à causa do Brasil ao jurarem a Constituição do Império de 1824, como uma mãe acolhe o filho adotivo. Nesse sentido, é fundamental considerar o enraizamento dos interesses portugueses antes ainda de 1808 , de modo a não permitir que o antilusitanismo tomasse a forma de qualquer tipo de ruptura mais séria. Gladys Ribeiro usou os trabalhos de João Fragoso a respeito do predomínio de negociantes portugueses de grosso trato estabelecidos no Rio de Janeiro para demonstrar como tais comerciantes apoiaram a causa da independência na defesa de seus interesses, que seriam prejudicados caso o país voltasse à condição da colônia (RIBEIRO, 2002: 97). Ademais, para a economia brasileira, era impensável expulsar os patrícios que por sinal movimentavam parte importante do comércio transatlântico, incluindo-se o tráfico de escravos (FRAGOSO, 1998:182).

Os conflitos que se deram entre brasileiros e portugueses eram inerentes a dinâmica da sociedade brasileira, remontavam à época da colônia e não seriam superados pelo Império. Em certo sentido foram conflitos endógenos numa estrutura de tempo de longa duração, mas que nunca significaram uma ruptura porque não se identificaram em geral com revoluções ou outros tipos de radicalismos. É possível enumerar três situações pontuais compreendidas entre o período colonial até fins do Segundo Reinado (1889) que explicam as causas dos embates entre portugueses e brasileiros.

No primeiro caso, se encontra as pressões sociais e raciais dos brasileiros contra o português rico monopolizador do comércio e dos cargos públicos. Logo, apresenta-se uma questão intrínseca à sociedade colonial. No segundo, vislumbra-se disputa entre o Partido Português e o Partido Brasileiro na gerência do Estado, uma disputa de poder. E por fim, no campo das vivências cotidianas relacionadas às lutas e embates pela sobrevivência no mercado de trabalho brasileiro, emergem os conflitos entre trabalhadores pobres portugueses e libertos e portugueses e escravos ao ganho que ocupavam funções bastantes, senão similares, nos mundos do trabalho: vendedores, carregadores. Nesse sentido, trata-se de uma disputa pelo espaço de trabalho, uma constante naquele cenário social da época (TERRA, 2013).

Maria Odila Leite Dias da Silva (2005: 28) vai mais longe e sugere que os portugueses enraizados no Brasil uniram-se à classe dominante nativa no combate ao haitianismo- medo das revoltas dos negros e contra as ameaças das revoltas regenciais do Norte e Nordeste. Essa aliança envolveria portugueses e brasileiros em seus 
interesses agrários, comerciais e administrativos do qual lançaram mão na tentativa de preserva a monarquia, a ordem e suas propriedades. Logo, observa-se mais a continuidade que a ruptura através destas chaves interpretativas.

No tocante às revoltas regenciais e seus significados, numa análise temporal do Império, há indícios baseados em estudos recentes de que as questões sócio-econômicas pesaram bem mais que as ideias. A difusão de um suposto constitucionalismo e dos ideais republicanos de Rousseau não parece ter sido fator considerável para justificá-las (MACHADO; NEVES, 1999: 69). A princípio tais tensões não aspiravam a uma ruptura inspirada por modelos mais democráticos de governo. Por esta razão, há certo grau de dificuldade em entender supostos movimentos numa ótica dialética de superações, no sentido de que as antíteses superariam as teses num movimento de tempo que produziria uma síntese. Um tratamento das revoltas do Primeiro Reinado e de algumas da Regência a partir do parâmetro da consciência social, conceito muito caro aos historiadores provenientes do marxismo cultural, em especial nas décadas 80 e 90 na historiografia brasileira, seria possível observar em alguns casos, uma espécie de Economia Moral tal qual nos assinalou Thompson (1998), isto é, em tempos de maior carestia, a estrutura econômica precipitaria descontentamentos latentes, situação que não se verificaria em época de estabilidade material naquele cenário social. Nesse parâmetro encontram-se Revoltas como a Cabanada 1832-1835 ocorrida em Pernambuco e Alagoas e Pernambuco e a Cabanagem no Pará entre os anos de 18351836.

Em ambas verifica-se como base do movimento índios, escravos e homens pobres livres, ou sertanejos que lutavam contra injustiças sociais e a escravidão A questão política local encontrava-se extremamente entrelaçada à questão social. No caso da Cabanada, primeiramente foram os senhores do engenho do açúcar quem capitaneavam as camadas pobres reclamando a atenção do governo central à província, mas a aliança foi rompida na medida que a revolta avançava e aprofundava-se, sobretudo nos traços anti-escravistas $\mathrm{Na}$ Cabanagem, excetuando-se a configuração social, a ideia na base também era a transformação do poder local, já que os presidentes de província nomeados não tomavam conhecimento dos problemas sociais do território que deveriam governar. Entrentanto, em nenhum dos dois casos, o separatismo vigorava como motivação primeira e inequívoca das revoltas.

A liderança política como diretriz do movimento social se expressa até mesmo no desenvolvimento da Revolta Farropilha no Rio Grande do Sul (1835-1845). Foram 
os caudilhos exaltados quem estiveram à frente do movimento e transformaram a província numa república com suas próprias leis, ainda que não fosse esse o objetivo inicial. Mesmo que a participação popular tenha sido fundamental para o êxito da Farropilha, sua razão política, que mobilizou todas outras demandas, residiu num princípio mais familiar aos ricos estancieiros que aos homens que trabalhavam sol a sol nos pampas. Afinal tratava-se de protestar contra a injusta carga tributária que o governo brasileiro impunha aos produtores de charque (PESAVENTO, 2017). Portanto, o separatismo foi medida extrema colocada em prática quando interesses econômicos dos caudilhos.

A partir desses exemplos, é possível notar que o separatismo, no período regencial, surgiu como consequência inevitável dos descotentamentos das províncias. Tratava-se de um mal, mas um mal menor. $\mathrm{O}$ fenômeno naquelas circunstâncias poderia ser exemplificado graficamente pela imagem de uma bandeira agitada quando interesses, sobretudo de raiz econômica, e no que tange ao usufruto do poder político de decisão, estivessem em risco ou seriamente comprometidos por uma política de Estado prejudicial aos grupos abastados de regiões afastadas do centro da monarquia e pela lógica da Economia Moral anteriormente citada. O objetivo de separar não era ordem do dia no período regencial, como já foi dito, era consequência inevitável. Pelo contrário, conservadores, regressistas e progressistas do período preocupavam-se, a priori, com a integridade do Império Brasileiro dando continuidade à configuração política do Primeiro Reinado.

Em outros movimentos onde foram atribuídas "radicalizações no período regencial" nota-se o transbordamento da atividade política dos grupos urbanos e letrados para as camadas pobres da população. Na Balaiada (Maranhão e Piauí 18381842), manifestos e panfletos criticavam diretamente teorias raciais em voga, que eram instrumentalizadas em prol da dominação social (ASSUNÇÃO, 1998: 87-89). Portanto, as ideias circulavam e chegavam a vários estratos sociais a partir de suportes culturais que lhes eram acessíveis.

Sendo assim, o período das Regências, se comparado ao Primeiro Reinado, trouxe consigo maior instabilidade no âmbito local e lembrava ao governo central recuperar a ordem, já que as ideias políticas haviam sido mobilizadas por estratos partidários na organização de revoltas com grande potencial de mobilização social. É bem verdade que em eventos como a Confederação do Equador, ainda no Primeiro Reinado, verificou-se uma dinâmica em certo sentido análoga. No entanto. no período 
regencial, as demandas multiplicaram-se para além do Nordeste. Não só a economia moral ou, o capitaneamento da massa levado a cabo por caramurus ou liberais moderados e exaltados que se utilizavam de manifestos, panfletos ou da palavra para insuflar o grosso da população explicam as revoltas: ao final, evidenciavam o sentimento de que a autoridade regencial era legal, mas ilegítima.

Uma análise mais ligeira, ou meramente quantitativa, até poderia deter-se na ruptura e na mudança que caracterizaram as revoltas do período regencial em relação a movimentos de contestação do Primeiro Reinado. O fato é que o horizonte de expectativa que regia aqueles que detinham o poder pautava-se pela preocupação com os valores da ordem, da civilização e também da propriedade. Sendo assim, o movimento de Regresso tomou as rédeas da Regência em 1837, a fim de barrar a anarquia. Bernardo Pereira de Vasconcelos talvez seja o exemplo mais bem desenhado da conversão do liberalismo em regresso. Sua motivação fundamentava-se na no zelo em preservar os valores que a elites do centro e da periferia, mais ou menos ilustradas, compartilhavam entre si. Valores que tornavam possível o pacto e a agregação. Seu discurso ao explanar os motivos que o levaram a deixar de ser liberal constitui uma síntese explicativa bem-acabada. Consequentemente, pode-se afimar ar um esforço pela continuidade para com os valores do Primeiro Reinado radicados em instituições sólidas, avessas a radicalizações e, sobretudo, preocupadas em impedir a fragmentação territorial. As leis de caráter centralizador visavam permitir a existência do aparato jurídico com o qual seria possível enquadrar e conter as agitações provinciais e conservara a integridade do país. Além disso, como apontou Richard Graham, em 1837, até as próprias elites locais passaram a temer mais a desordem do que o poder central. (GRAHAN, 1997: 74-76)

Portanto, importantes historiadores, como aqueles aqui citados, escreveram obras referentes ao período, em que a antítese histórica própria da dialética hegeliana ou marxista não aparece como opção teórica aplicada na prática para a explicação do período regencial. As revoltas não são antíteses (o não ser) que produzem sínteses (o devir) capazes de romper com o equilíbrio e a ordem presentes no "ser" do regime imperial brasileiro anterior a abdicação (tese), tal qual o modelo filosófico. Não há uma síntese radicada na mudança social como o previu Marx e Engels (1977), nem tampouco uma síntese que consiste na criação de um Estado Moderno e democrático 
como o disse Hegel (2008). ${ }^{3}$ O produto das agitações regionais no Império do Brasil não se apresenta a modo de síntese, ao contrário, constitui o retorno à centralização política e administrativa nos moldes da reinterpretação do Ato Adicional de 1834 que tolhia ainda mais liberdades diversas. Em suma, em 1837 busca-se o progresso pela ordem conservando-se as hierarquias, mas não a liberdade.

\section{Rupturas lentas e tardias do Segundo Reinado}

À medida que o tempo avança, é perceptível, pelo menos até o final da década de 1850, a concretização de um projeto conservador, levado a cabo, inicialmente, por grupos políticos ligados aos plantadores fluminenses, no momento em que o plantation de café encontrava-se em seu auge naquela região. Eram os saquaremas. O projeto baseava-se na conservação da propriedade, manutenção da escravidão, conservação da unidade do terriório, convivência natural com o tráfico de escravos e promoção da agricultura para o progresso. Tratava-se de uma direção política, intelectual e moral pela boa sociedade. De fato, os liberais de revoltas de 1842, em Minas Gerais, chamados luzias, e os liberais de1848, em Pernambuco, opuseram-se à direção política dos saquaremas, sobretudo, por questões de autonomia politica-adminsitrativa nas províncias. No entanto, concordamos que tais liberais foram capitaneados para o projeto saquarema, na década de 1850, já que o que se viu foi o predomínio da uma "boa sociedade" formada por brancos livres e proprietários de escravos, aqueles que eram aptos para reger bem o mundo do governo em oposição ao mundo do trabalho formado pelos escravos (MATTOS, 1994: 109). Por esse motivo, Ilmar Mattos afirmou que conservadores e liberais não eram opostos, mas complementares, já que seus ideiais de escravidão e ordem coincidiam (MATTOS, 1994: 105-106).

O que ocorreu foi que os saquaremas por meio da aplicação de leis e fazendo uso dos meios letrados detiveram as prerrogativas e as narrativas sobre a construção do Império até inícios da década de 1860 (MATTOS, 1994). Foram eficazes ao afastar a política das ruas, como acontecia na época da Regência, para trazê-la à casa, entendida como a direção do Estado.

\footnotetext{
3 No Idealismo Absoluto de Hegel o movimento ternário do Espírito se dá no tempo e tem como resultado o devir, ou a autoconsciência. O Estado Moderno, a via moral que encarna a liberdade e a razão constitui o resultado dessa dialética. Já Para Marx e Engels o devir ou síntese é a revolução, que por sua vez é o produto dos conflitos de classes que produzem essa nova realidade social.
} 
Um projeto único para civilizar a família patriarcal, constituir a classe senhorial e conformar os brasileiros. Dessa forma, se concretizou na administração das províncias a ideia de constituição de uma classe senhorial que devido a uma comunidade de interesses estaria ligada a tríade Conservadora Fluminense formada pelos políticos e burocratas: Eusébio de Queirós, Joaquim José Rodrigues Torres e Paulino José Soares de Sousa. Como já foi dito, os liberais dissidentes foram incapazes de estar à frente desse projeto, mas em certo sentido, se enquadraram à direção saquarema, na medida em que comungavam dos principais interesses da classe senhorial, destacando-se a propriedade escrava e a monarquia como instituição garantidora da civilização. "Os liberais de 1842 e 1848 foram capitaneados pela boa sociedade” (MATTOS, 2009: 51). As revoltas da década de 1840 constituíram os últimos ecos dos conflitos internos das elites que marcaram o período regencial. Em outras palavras, as diferenças regionais eram deslocadas em proveito de uma nova identidade nacional, pautada pela boa sociedade.

Por isso, as décadas de 1840-1850, sobretudo, garantiram a construção do futuro, ordenando a casa, deixando as ruas um pouco mais vazias. Não se trata de um mero retorno aos primeiros anos da Corte no Brasil num movimento quase circular, afinal a geração de homens do Segundo Reinado não era a mesma da Independência ou do período anterior a ela. Tratava-se sim de resgatar o sentido de nação e liberdade, mas com uma ênfase ainda mais sublinhada no ideal de unidade. O governo imperial levaria a cabo durante o Gabinete do Marquês de Paraná (1853-1856) a Política da Conciliação, uma tentativa do governo conservador de aproximar os liberais que radicalizaram no passado.

A década de 1860 traz consigo novos interesses de grupos afastados do poder, que se tornam mais proeminentes. São eles mais capazes de pensar outro horizonte de expectativa pautado por um espaço de experiência que não se coaduna mais com o projeto saquarema, uma vez extintos os perigos de desintegração territorial. Em 1860 os liberais venceram as eleições para a Câmara e figuras como os irmãos Teófilo e Cristiano Ottoni, ativos em Minas, voltaram ao cenário político. Por meio do movimento denominado Liga Progressista, indivíduos com tendências políticas anteriormente opostas se uniram contra os chamados emperrados, isto é, conservadores 
que não aceitaram a conciliação e permaneceram resistentes a qualquer negociação com outras lideranças partidárias (HOLANDA, 1976: 87). ${ }^{4}$

Tal união, precipitada pela eleição de uma câmara de maioria liberal, não nos enganemos, era direcionada também pela questão dos interesses pessoais no campo político em uma conjuntura específica. Teófilo Ottoni, por exemplo, entrou para a Liga logo depois de ser rejeitado pelo Imperador para ocupar uma vaga no Senado. (BARBOSA, 2001: 353-354). A adesão ao movimento seria uma forma de lutar pela participação em outros gabinetes e vencer resistências levantadas pelos emperrados. Já antigos conservadores que também se afastavam dos emperrados como Zacarias de Góis e Vasconcellos e o Nabuco de Araújo também tinha lá seus motivos. Nabuco expuserase em nome dos conservadores nos negócios do Império ao coordenar o aluguel da pena dos jornalistas. Quando foi execrado pela imprensa, os conservadores nada fizeram para defendê-lo perante tais acusações. Zacarias esperou uma nomeação para o Ministério que não saiu em 1862 (MOMESSO, 2015: 293).

Em meio a esse clima de distensão dá-se a nova aliança ligueira que se apresenta como reformista e moderada, já que deve ajeitar múltiplos interesses em seu interior. Tem início um tempo de reforma que se prolonga até a década de 1870, inicialmente marcado por propostas de descentralização administrativa, mas não política e, sobretudo pelo emancipacionismo, isto é abolição lenta e gradual da escravidão. Tratava-se de um conjunto de ideias, primeiramente, influenciadas pelo liberalismo inglês, que via na escravidão uma instituição de entrave para o progresso, por vezes também, inspirada em chaves filosóficas religiosas. O conservador Perdigão Malheiro autor do livro a Escravidão no Brasil (1866) e o ministro da justiça Nabuco de Araújo faziam parte desse grupo em franca oposição com os emperrados. Malheiro afirmava que o escravo era propriedade segundo a lei, o que na prática era uma ficção legal, porque segundo a natureza, em termos ontológicos tratava-se de uma pessoa. A lei criava a propriedade, mas a propriedade não anulava a natureza humana. Nabuco por sua vez encarregado pelo imperador de atuar como relator na Comissão para a Redação para Lei da

\footnotetext{
4 O primeiro a empregar o termo "emperrados" foi Zacarias de Góis e Vasconcellos, dai que diferentes gerações de historiadores usaram-no para fazer referência aos membros do Partido Conservador que mantiveram sua posição partidária e opiniões doutrinais inalteradas ao longo de todo Segundo Reinado e, portanto, não aderiram a Liga Progressista. Em geral, permaneceram resistentes a qualquer tipo de negociação com as províncias e com outros partidos, eram favoráveis à concentração de atribuições ao poder Moderador e não mostraram entusiasmo a nenhum tipo de projeto emancipacionista.
} 
Emancipação Gradativa passou a reiterar no jornal A Reforma, seguidamente que o escravo era pessoa e não coisa, usando o termo de modo continuado em editorias.

Ambos defendiam a abolição gradativa mediante indenização aos proprietários. No caso de Nabuco, além da convicção pessoal de que o Brasil ficaria atrasado em relação à Europa caso continuasse a defender o emprego da mão de obra escrava, ao que parece, existia o interesse de diferenciação e protagonismo político em relação a plataforma dos conservadores. Ele foi o primeiro político a incorporar a proposta da emancipação dos escravos no programa do Movimento Centro Liberal, em 1869. Ainda que reconhecesse não ser essa a primeira questão do partido, chamou atenção para o tema, assinalando a necessidade da medida para o futuro do Brasil (CARVALHO, 2007: 15).

No final dos anos de 1860, o próprio Dom Pedro II converteu-se num reformista. Em 1867 na Fala ao Trono trouxe a tona a necessidade da substituição do elemento servil - termo atenuante lançado pelo monarca para designar o escravo (FALAS AO TRONO, 1867: 203). Após a guerra do Paraguai, a situação econômica agravava-se, o prestígio da escravidão começou a declinar e a volta de apenas uns poucos escravos que conseguiram sua liberdade lutando nas batalhas já era um signo perigoso capaz de incitar desordens. O prejuízo seria maior caso não se pensasse em uma solução para a mudança do tipo de mão de obra empregada nas lavouras brasileiras.

Em todo caso, se notam os novos horizontes que direcionam a ação presente. Tem-se início um tempo de rupturas lentas e prudentes, levada a cabo ainda por grupos limitados de políticos que seguiam perspectivas pautadas por ideologias e interesses. Para eles não existia revolução, mas a reforma, sem dúvida, era urgente. Seguindo essa lógica, a geração subsequente, a de 1870, aprofunda e agudiza tais ideias, já que o cativeiro está com os dias contados e a alguns políticos do oeste Paulista já tinham desencadeado o processo de imigração europeia (BOSI, 1992: 194-245).

Angela Alonso demonstra que a defesa de posições acentuadas tem a ver, por um lado, com o "bando de ideias novas" disponíveis aos homens letrados envolvidos na política como, por exemplo: Joaquim Nabuco, André Rebouças, Quintino Bocaiúva, Salvador de Mendonça e Miguel de Lemos. A apropriação ideológica fornece a base para a formação de novos grupos doutrinários nos anos de 1870: os novos liberais, os liberais republicanos, os abolicionistas positivistas e os federalistas de São Paulo e do Rio Grande do Sul. Contudo, mais elucidativo parece ser a explicação de tais apropriações, a partir do lugar de cada um desses grupos distribuídos em "círculos 
concêntricos de distanciamento progressivo em ralação a um ou ambos os centros de poder do Império" (ALONSO, 2009: 87): o poder social da sociedade de corte, cujo núcleo era o imperador, e o poder político, o controle de instituições do regime, sob hegemonia do Partido Conservador.

Sendo assim surgiram novas posições políticas que romperam com elementos da tradição saquarema, embora não de modo brusco. Alguns falavam, por exemplo, da República, ainda que admitissem esperar a morte de Pedro II para implantá-la sem radicalizações. Outros falavam da abolição pela via parlamentar, legal, preocupando-se com a sorte do escravo no pós-abolição, já que nisso residia também a continuidade econômica do país. Uma vez que a maioria dos participantes desse grupo estava em maior ou menor grau afastada do poder político ou econômico, sentiam-se a vontade para tecer certa crítica mais veemente.

Nesse sentido, cabe a observação de Keith Baker. Para o historiador, elementos de novas culturas políticas são herdados de culturas políticas precedentes, apesar das rupturas. $O$ processo que nada tem que ver com uma síntese, consiste numa reelaboração tendo em vista conjunturas históricas, interesses, ideias e linguagens disponíveis (BAKER, 1989: 11-24). A geração de 1870, constituída por homens de estratos altos e médios da população, apesar do espírito contestador temia mudanças bruscas que desestabilizassem a ordem, sobretudo depois da Guerra do Paraguai, quando o Brasil encontrava-se em situação econômica frágil. Qualquer tipo de revolta popular que fugisse ao controle do Estado deveria ser evitada, exatamente nisto repetiam a tradição saquarema. Seu reformismo inspirara-se, ademais, nos pressupostos dos emancipacionistas como Nabuco de Araújo e Perdigão Malheiro, em voga nos finais da década de 1860 .

Por fim, caberia lembrar que, de fato, é possível descortinar uma proposta de revolução em sentido estrito e inversão da ordem social vigente em pleno Império. Isso torna se viável na abordagem de algumas revoltas como a dos Malês em 1835, ainda no período anterior às leis anti-tráfico ou emancipacionistas ou perante a análise da atuação de alguns agentes do movimento abolicionista como Luiz Gama, entre as décadas de 1860 e 1880.

Na Revolta dos Malês, exaustivamente investigada por João José Reis, dá-se um caso em que se entrelaçam a religião (islamismo) a classe (escrava) e a etnia (malê) como fatores que possibilitam a intensa rebeldia do movimento (REIS; SILVA, 1989: 122). Os momentos de erupção da rebeldia escrava estavam vinculados à micropolitica 
do cotidiano, das relações de poder na sociedade civil. No candomblé viviam suas tradições e também conspiravam.

Luiz Gama (1830-1882), rábula, abolicionista e poeta buscava afirmar a identidade negra, fazendo uso inclusive da arte. Seus versos satíricos teriam servido para marcar o espaço dos africanos na vida política. Elciene Azevedo ressalta que Gama procurava edificar um campo de igualdade, no qual os negros teriam o direito de construir para si mesmos espaços de autonomia e, principalmente, de liberdade. Ele foi o autor da frase polêmica que conturbou o júri na segunda metade do século XIX: "O escravo que mata o senhor, seja em que circunstância for, mata sempre em legítima defesa" (AZEVEDO, 1999: 77).

\section{Conclusão}

Ao longo desse breve percurso através dos modos de se pensar, construir e protagonizar a História no Império Brasileiro no século XIX, observou-se mais continuidades e descontinuidades que sínteses. Na verdade, a continuidade foi explicada na escrita da história do Brasil Império pelas heranças e tradições abordadas pela História Intelectual quando trata das culturas políticas em combinação com os conflitos genuínos mais localizados no âmbito da participação da atuação autônoma das massas em momentos específicos, sobretudo em revoltas escravas e no agir genuíno de exescravos e abolicionistas como Luiz Gama, ele mesmo um caso excepcional, um ponto fora da curva.

No âmbito do IHGB nota-se a preocupação em programar o futuro e garantir o presente pela narração da história de uma nação coesa e agrupada em torno da monarquia. Mesmo quando o Império já havia findado, o Instituto fazia uma narrativa laudatória daquela a época, vivendo um regime de historicidade fundado no passado. Caberia, nesse caso, a afirmação de François Hartog: "o modo de ser do passado é o do seu surgimento no presente, mas sob o controle do historiador" (HARTOG, 2013:161).

Durante o período de Independência e Regência, a historiografia aqui estuda apontou a imensa preocupação em viver um presente onde a ordem imperasse, custe o que custasse. O liberalismo emergente foi então conservador: apregoou a modernidade, mas conservou a propriedade e o voto censitário, tratou da liberdade econômica, porém foi excludente quando o tema eram os direitos políticos. Nas revoltas regenciais, salvo 
exceções, o povo foi massa de manobra, ainda que lutasse legitimamente nas ruas e nos campos por suas demandas e obtivesse sua própria experiência cultural a partir desses embates. Nessas obras, fica claro que as experiências republicanas foram localizadas e explicadas mais por interesses práticos que por questões ideológicas. O regresso contornou tais conflitos.

No Segundo Reinado, vislumbraram-se mudanças que romperam a tradição saquarema. No entanto as mesmas transformações, explicadas por questões geracionais e pelo lugar ocupado em relação ao poder monárquico e ao partido conservador, foram lentas em si. Grande parte dos abolicionistas pensava na liberdade do escravo de modo a enquadrá-lo no funcionamento da sociedade estável, numa posição confortável às classes altas e médias. Mas, graças às exceções apresentou-se também uma chispa de movimento dialético que se opôs ao liberalismo conservador, e permitiu a visão de algo mais que "moderação" na História do Império. Dessa combinação entre moderação e rebelião, surgem novas circunstâncais, fruto da liberdade pessoal de cada agente articulado em suas redes, distinto por vezes do previsível e lógico. Tal quadro aparece, no entanto, após uma longa duração e conserva critérios de ordem e hierarquia social existentes nos ínícios da História Imperial brasileira.

Ao tratar da temporalidade do Império Brasileiro caberia também abordar as clivagens que o liberalismo assumiu ao longo do período, mas isso servirá de tema para outra ocasião.

\section{Fontes}

FALAS AO TRONO [1977]. Desde o ano de 1823 até o ano de 1889. Pref. Pedro Calmon. Brasília: INL.

SÃO LEOPOLDO, Visconde [1842]. Discurso a sua Magestade no aniversario de seu natallicio. R.IHGB, Rio de Janeiro, vol. 4, n. 13, pp. 519-530, dez. Disponível em: $<$ https://drive.google.com/file/d/0B_G9pg7CxKSsMG13UHpyWElja0U/view $>$. Acesso em: 12 ago. 2018.

TAUNAY, Visconde [1914] Notas de Pedro II. R.IHGB. Rio de Janeiro, tomo 78, pp. 69-80. Disponível em: $<\quad$ https://ihgb.org.br/publicacoes/revistaihgb/itemlist/filter.html?searchword438-from=1914\&searchword438to=1914\&modul >. Acesso em: 12 ago. 2018.

REVISTA DO INSTITUTO HISTÓRICO E GEOGRAPHICO BRASILEIRO [1917]. Edição sobre a Independência do Brasil. Rio de Janeiro, n. 79, 1917. Disponível em: 〈https://drive.google.com/file/d/0B_G9pg7CxKSsajY1UEtEdFBhc2M/view〉. Acesso em: 12 ago. 2018. 


\section{Referências Bibliográficas}

ALONSO, Angela (2009). Apropriação de Ideias no Segundo Reinado. In: GRINBERG, Keila; SALLES, Ricardo. (Org.). O Brasil Imperial 1870-1889. Rio de Janeiro: Civilização Brasileira, vol. 3, pp. 85-118.

ASSUNÇÃO, Mathias Rohring (1998). Histórias do Balaio: historiografia, memória oral e origens da Balaiada. Revista Brasileira de História Oral. São Paulo, n.1, pp. 67-89.

AZEVEDO, Elciene (1999). Orfeu de carapinha: a trajetória de Luiz Gama na imperial cidade de São Paulo. Campinas: Editora da UNICAMP, Cecult.

BAKER, Keith (1989). Introduction. In: BAKER, Keith (Ed.). The French Revolution and the Creation of Modern Political Culture: the Political Culture of Old Regime. Oxford: Pergamon, vol. 1, pp. XI-XXIV.

BARBOSA, Silvana Mota (2001). A Sphinge Imperial: o poder moderador e a política Imperial. Tese (Doutorado). Universidade Estadual de Campinas.

BOSI, Alfredo (1992). Dialética da Colonização. Rio de Janeiro: Companhia das Letras.

CARVALHO, José Murilo de (1996). Cidadania: Tipos e Percurso. Estudos Históricos. Rio de Janeiro, vol. 9, n.18, pp. 337-360.

(2007). Liberalismo, radicalismo e republicanismo nos anos sessenta do século dezenove. Working Paper 87. Oxford: Center for Brazilian Studies, University of Oxford. Disponível em: <http;//www.brazil.ox.ac.uk/-data/assets/pdf file/0003/9327/WP87-murilo. pdf>. Acesso em: 03 ago. 2018.

DIAS, Maria Odila da Silva Leite. Aspectos da Ilustração no Brasil. RIHGB. Rio de Janeiro, n.278, p.105 - 170,1968.

DIAS, Maria Odila da Silva Leite (2005). A interiorização da metrópole e outros estudos. $2^{\text {a }}$ Edição. São Paulo: Alameda.

FRAGOSO, João Luís Ribeiro (1998). Homens de Grossa Aventura: Acumulação e Hierarquia na Praça Mercantil do Rio de Janeiro. 2a ed. Rio de Janeiro: Civilização Brasileira.

GRAHAM, Richard (1997). Clientelismo e Política no Brasil do século XIX. Rio de Janeiro: Ed. da UFR.

GUIMARÃES, Lúcia Maria Paschoal (2006). Circulação de Saberes, Sociabilidades e Linhagens Históricas: dois Congressos de História Nacional (1914-1949). In. GUIMARÃES, Manoel Luiz Salgado. Estudos sobre a escrita da História. Rio de Janeiro: 7 Letras, pp.162- 181.

GUIMARÃES, Lúcia Maria Paschoal (2011). Debaixo da Imediata Proteção Imperial. São Paulo: Annablume.

GUIMARÃES, Manoel Luis Lima Salgado (1988). Nação e Civilização nos Trópicos: o Instituto Histórico Geográfico Brasileiro e o projeto de uma história nacional. Estudos Históricos. Rio de Janeiro, vol.1, n.1, pp. 5-27.

HARTOG, François (2013). Regimes de Historicidade. Presentismo e Experiências do Tempo. Belo Horizonte: Autêntica Editora.

HEGEL, Georg W. Friedrich (2013). A Razão na História. Coleção Textos Filosóficos. Rio de Janeiro:Edições 70. 
HEGEL, Georg W. Friedrich (2008). Lições de Filosofia da História. Brasília: UNBEDU.

HOLANDA, Sergio Buarque de (1976). História Geral da Civilização Brasileira. $3^{\mathrm{a}}$ ed. Rio de Janeiro: Difel, t. 2, vol. 3, pp. 85-107.

KOSELlECK, Reinhart (2006). Futuro Passado. Contribuição à Semântica dos Tempos Históricos. Trad. Wilma Patrícia Mass e Carlos Ameida Pereira; revisão. Rio de Janeiro: Contraponto; Ed. PUC-Rio.

LYRA, Maria de Lourdes Vianna (1994). A Utopia do Poderoso Império. Rio de Janeiro: Sete Letras.

MACHADO, Humberto; NEVES, Lúcia Maria Bastos Pereira das (1999). O Império do Brasil. Rio de Janeiro: Nova Fronteira.

MARX, Karl; ENGELS, Frederich (1997). A ideologia Alemã. São Paulo: Grijalbo.

MATTOS, Ilmar R (1994). O Tempo Saquarema. Rio de Janeiro: Acess.

MOMESSO, Beatriz Piva Momesso (2015). Letras, Ideias e culturas políticas: os escritos de Nabuco de Araújo (1843-1876). Tese (Doutorado em História Política), Universidade do Estado do Rio de Janeiro.

NEVES, Lúcia Maria Bastos P. das |(2003). Corcundas e Constitucionais. A Cultura Política da Independência (1820-22). Rio de Janeiro: Ed Revan.

PESAVENTO, Sandra Jatahy (2017). Uma certa revolução Farropilha. In. Grinberg, Keila; SALLES, Ricardo (Orgs.). O Brasil Imperial, vol. II, 4ª edição. Rio de Janeiro: Ed. Civilização Brasileira.

REIS, João José; SILVA, Eduardo (1989). Levante dos Malês: uma interpretação política. In: Negociação, Conflito e Resistência Negra no Brasil Escravista. São Paulo: Cia das Letras, pp. 99-122,

RIBEIRO, Gladys Sabina (2002). Ser Português ou Ser Brasileiro. In. RIBEIRO, Gladys Sabina. A liberdade em construção: identidade nacional e conflitos antilusitanos no Primeiro Reinado. Rio de Janeiro: Relume Dumará, pp.27-142.

SILVA, Cristina Nogueira da (2002). Nação, territórios e populações nos textos constitucionais portugueses do século XIX. Revista da Faculdade de Direito da UNL. Lisboa, ano III, n.5, pp.61-71.

SLEMIAN, Andrea (2005). Seriam todos cidadãos? Os Impasses na Construção da Cidadania nos primórdios do constitucionalismo no Brasil (1823-1824) In. JANCSÓ, István. Independência: história e historiografia. São Paulo: Ed. Hucitec, pp. 829-847.

TERRA, Paulo Cruz. (2013) Cidadania e trabalhadores: cocheiros e carroceiros no Rio de Janeiro (1870-1906). Rio de Janeiro: Secretaria Municipal de Cultura: Arquivo Geral da Cidade do Rio de Janeiro.

THOMPSON, E. P. (1998) Costumes em comum. Estudos sobre a cultura popular tradicional. São Paulo: Companhia das Letras.

Artigo recebido em 28 de agosto de 2018.

Aprovado em 15 de fevereiro de 2019.

10.12957/intellectus.2019.36828 